\title{
Orientin Alleviates Liver Inflammation via Downregulation of ZEB-2/PTEN Markers-Hepatic Stellate Cells Approach
}

\author{
Hany Ezzat Khali1 1,2,*(D), Hairul-Islam Mohamed Ibrahim ${ }^{3,4}{ }^{\oplus}$, Kareem Ahmed El-Fass ${ }^{5}$, Sabah H. Akrawi ${ }^{1}$ \\ and Mohamed A. Morsy 1,6 \\ 1 Department of Pharmaceutical Sciences, College of Clinical Pharmacy, King Faisal University, \\ Al-Ahsa 31982, Saudi Arabia; sakrawi@kfu.edu.sa (S.H.A.); momorsy@kfu.edu.sa (M.A.M.) \\ 2 Department of Pharmacognosy, Faculty of Pharmacy, Minia University, Minia 61519, Egypt \\ 3 Department of Biological Sciences, College of Science, King Faisal University, Al-Ahsa 31982, Saudi Arabia; \\ himohamed@kfu.edu.sa \\ 4 Department of System Biology, Pondicherry Center for Biological Science and Educational Trust, \\ Kottakuppam 605104, India \\ 5 Department of Pharmacy Practice, College of Clinical Pharmacy, King Faisal University, \\ Al-Ahsa 31982, Saudi Arabia; kelfass@kfu.edu.sa \\ 6 Department of Pharmacology, Faculty of Medicine, Minia University, Minia 61511, Egypt \\ * Correspondence: heahmed@kfu.edu.sa
}

check for

updates

Citation: Khalil, H.E.; Ibrahim, H.-I.M.; El-Fass, K.A.; Akrawi, S.H.; Morsy, M.A. Orientin Alleviates Liver Inflammation via Downregulation of ZEB-2/PTEN Markers-Hepatic Stellate Cells Approach. Appl. Sci. 2022, 12, 2725. https://doi.org/10.3390/app12052725

Academic Editors: Anca Pop,

Felicia Loghin, Catalina Bogdan and Ionel Fizesan

Received: 9 February 2022

Accepted: 4 March 2022

Published: 6 March 2022

Publisher's Note: MDPI stays neutral with regard to jurisdictional claims in published maps and institutional affiliations.

Copyright: (C) 2022 by the authors. Licensee MDPI, Basel, Switzerland. This article is an open access article distributed under the terms and conditions of the Creative Commons Attribution (CC BY) license (https:// creativecommons.org/licenses/by/ $4.0 /)$.

\begin{abstract}
Liver inflammation is associated with an increased risk of liver fibrosis that substantially progresses to cirrhosis. Recently, usage of the herbal supplement has been increased because of its emerging role to dominate oxidative stress in hepatic injury. Orientin is one of the bioactive flavonoids that possesses a diversity of curative activities. Therefore, the present study was conducted to evaluate the anti-inflammatory role of orientin $(1 \mathrm{mg} / \mathrm{kg})$ in vitro in lipopolysaccharide (LPS)induced inflammation in hepatic stellate cells (HSCs) and in vivo in carbon tetrachloride $\left(\mathrm{CCl}_{4}\right)$ induced liver fibrosis in mice. Moreover, the current study was supported by in silico investigation. Orientin demonstrated protection against LPS-induced HSC inflammation as evidenced by a decrease in iNOS, NO, and TNF- $\alpha$ and inhibition of the fibrotic markers ZEB-2 and PTEN. In addition, orientin afforded protection against $\mathrm{CCl}_{4}$-induced liver fibrosis in mice as shown from decreased AST/ALT ratio, inhibition of the pro-inflammatory mediators TNF- $\alpha$, IL- 6 , IL-8, and IFN- $\gamma$, reduction of fibrotic markers ZEB-2 and PTEN, and improvement of the histopathological changes. Furthermore, the docking study demonstrated virtual interactions of orientin with ZEB-2 and PTEN. Taken together, the current study suggested that the protective effects of orientin against LPS- and $\mathrm{CCl}_{4}$-induced liver inflammation are via inhibition of fibrotic markers and reduction of pro-inflammatory mediators.
\end{abstract}

Keywords: orientin; ZEB-2; PTEN; TNF- $\alpha$; iNOS; hepatic stellate cells

\section{Introduction}

Liver inflammation is one common initiator of liver illness and is considered as the main contributor of hepatic tissue damage [1]. Consequently, inflammation leads to tissue modifications with the developing of fibrosis, cirrhosis, and finally, in many cases ending in primary liver cancer, and death [2,3]. Worldwide, more than 1 million deaths each year are due to the chronic liver inflammation associated with fibrosis and cirrhosis [4]. Inflammation of injured hepatocytes activates immune processes in liver. Inflammatory signaling of the liver is regulated by the action of immune cells, including Kupffer cells and inflammatory cells, such as infiltrating macrophages, $\mathrm{T}$ lymphocytes, neutrophils, and dendritic cells [5]. Consequently, such processes initiate and maintain the hepatic inflammation through the release of cytokines, such as zinc finger e-box binding protein 2 (ZEB-2), phosphatase and tensin homolog (PTEN), tumor necrosis factor (TNF- $\alpha$ ), interleukins (IL-1 and IL-6), as well as interferon gamma (IFN- $\gamma$ ) [6-10]. These inflammatory mediators 
activate hepatic stellate cells (HSCs), which are the major source of the development of fibrosis in liver after interaction with HSCs via transforming growth factor (TGF- $\beta$ ) [1].

Flavonoids are a group of natural products which are important for human health [11]. Flavonoids exhibit broad therapeutic potential in cardiovascular, gastric, and liver diseases. Furthermore, flavonoids exhibited anti-inflammatory properties through regulation of inducible nitric oxide synthase (iNOS), cyclooxygenase-2 (COX-2), and other inflammatoryrelated factors [12-18]. Among these flavonoids, the C-glycosylated type including orientin, isoorientin, vitexin, and isovitexin are reported to possess anxiolytic, antioxidative activities $[19,20]$. Orientin is one in this bioactive category isolable from many medicinal plants such as basil, bamboo, passion flower, golden queen, flax, dayflower, and lavender. Orientin exhibits a diversity of medicinal properties, which comprise anti-inflammation, antioxidant, antimicrobial, neuroprotective, vasodilation, and cardio-protective effects [19,21]. Carbon tetrachloride $\left(\mathrm{CCl}_{4}\right)$ is commonly used in industries as a solvent and in medicine as an anthelmintic. $\mathrm{CCl}_{4}$ is a well-known hepatotoxic in both humans and experimental animals. Previous studies reported its wide application in scientific research including flavonoids, as a model of hepatotoxicity associated with the release of TNF- $\alpha$ from activated hepatic macrophages [22-24]. Lipopolysaccharide (LPS) is an endotoxin made up of a polysaccharide and induces inflammation in various organs, including the liver, kidney, and brain, as well as murine macrophages and HSCs. Most of the toxicities observed in LPS-induced injury have been attributed to toxic mediators produced by activated cells, including TNF- $\alpha$, iNOS, IL-1 $\beta$, IL-6, ZEB-2, PTEN, and other pro-inflammatory molecules [25-29]. However, to the best of our knowledge, there was no previous detailed information about the effects of orientin on LPS-mediated pro-inflammatory responses on HSCs, as well as its anti-inflammatory activity towards $\mathrm{CCl}_{4}$-induced liver inflammation on experimental mice. Hence, the current study was designed to assess the effect of orientin on anti-inflammatory activity and its molecular mechanisms towards a $\mathrm{CCl}_{4}$-induced in vivo model and inflamed in vitro model including an in silico docking approach.

\section{Materials and Methods}

\subsection{Animals and Experimental Design}

Male C57Bl6j mice (at age of 6-8 weeks and weight range 20-25 g) were maintained in the College of Science, King Faisal University and accommodated in animal ethical conditions with a 12/12 h light/dark cycle and unrestricted access to nutrition conditions. Animal protocols were approved by the Deanship of Scientific Research (KFU-REC-2022JAN-EA000401), King Faisal University, Saudi Arabia, and all animal experiments conformed to the appropriate standards. $\mathrm{CCl}_{4}$ was used to induce liver injury models. Mice were divided into four groups as follows: control group (corn oil was administered via oral gavage); inflammatory group ( $15 \% \mathrm{CCl}_{4}$ (Merck-Sigma, Darmstadt, Germany) was used at a concentration of $5 \mathrm{~mL} / \mathrm{kg}$ twice a week); inflammatory and orientin group $(1 \mathrm{mg} / \mathrm{Kg}$ body weight of orientin (Carbosynth, Rietlistrasse, Staad, St. Gallen, Switzerland) was injected via intra peritoneal); and orientin alone group $(1 \mathrm{mg} / \mathrm{Kg}$ was injected via intra peritoneal). HCSs were extracted in naïve mice and extracted cells used for ex vivo inflammatory studies. To assess the effect of orientin on liver protection and anti-inflammatory properties, the mice were sacrificed 3 weeks after injection.

\subsection{Isolation and Culture of Primary Hepatic Stellate Cells}

HSCs were isolated from male C57Bl6j mice as described previously [30]. Briefly, after in situ perfusion of the liver with 2-step proteinase-collagenase digestion, and HSCs were maintained in RPMI (Sigma-Aldrich, Taufkirchen, Germany) supplemented with 10\% fetal bovine serum (Applied Biosystems, Waltham, MA, USA) and 1\% anti-mycotic/antibacterial solution (Gibco, Waltham, MA, USA) at $37^{\circ} \mathrm{C}$ in humidified conditions with $5 \% \mathrm{CO}_{2}$. The purity of cells was quantified by a Bio-Rad cell counter. The media were changed after the 5th day of culture. The cultured cells were regarded to be HSCs and used to carry 
out experiments after 3 passages. Orientin- and $\mathrm{CCl}_{4}$-supplemented cell treatments were initiated $12 \mathrm{~h}$ after isolation.

\subsection{Estimation of Cytokines for Liver Inflammation}

HSCs were plated into 6-well plates, and when the cells were $80 \%$ confluent, $10 \mathrm{ng} / \mathrm{mL}$ LPS was added for $12 \mathrm{~h}$. The cytokines from HSCs derived from liver tissue of naïve mice were quantified. Cayman scientific kits (Cayman Chemical Co., Ann Arbor, MI, USA) were used to quantify the TNF- $\alpha$, IL-6, IL-8, and IFN- $\gamma$ according to manufacturer instructions.

\subsection{Nitrate Detection Assay}

HSC s were cultured into 6-well plates, and at $80 \%$ of cells confluent, $10 \mathrm{ng} / \mathrm{mL}$ of LPS was inserted for $12 \mathrm{~h}$. After that, $1 \mathrm{~mL}$ of fresh serum-free media was inserted into the culturing plate. Adjusted experimental media were cropped after $24 \mathrm{~h}$. Nitric oxide in experimentally adjusted medium was evaluated by Griess assay (Beyotime Biotechnology, Shanghai, China) according to the manufacturer's protocol [31].

\subsection{RNA Extraction and RT-PCR Analysis}

In brief, the cell culture dish was embedded on ice, TRIzol (Thermo Fisher, San Jose, California, USA) was added to lyse the cells for 5-10 min, and then followed by the method described in Khalil et al. [30]. Then, total cellular RNA was extracted according to the manufacturer's protocol. One microgram of total RNA was reverse transcribed using the Prime Script TM RT-reagent kit (Takara, RR047A, Kusatsu, Shiga, Japan) [32].

The primer sequences used for amplification were as follows: GAPDH forward, $5^{\prime}$ GCAAGGATACTGAGAGCAAGAG-3' ${ }^{\prime}$ and reverse, $5^{\prime}$-GGATGGAATTGTGAGGGAGATG$3^{\prime}$; ZEB-2 forward, 5' -AGCGACACGGCCATTATTTAC-3' reverse, 5'-GTTGGGCAAAAGC ATCTGGAG-3'; PTEN forward, 5'-TGTGGTCTGCCAGCTAAAGG-3' and reverse, 5' ACACACAGGTAACGGCTGAG-3'.

\subsection{Western Blot}

An overnight incubation of cells was performed prior to exposure to the specified treatments. The lysates of cultured cells were prepared using RIPA lysis buffer, then separated on an SDS-PAGE gel and transferred to a PVDF membrane. Western blot assays were performed with the aid of specified primary antibodies: ZEB-2 (mouse monoclonal antibody 1:1500) (Invitrogen, Waltham, MA, USA), PTEN (rabbit polyclonal antibody 1:1000) (Invitrogen, Waltham, MA, USA), iNOS (rabbit polyclonal antibody 1:1000) (Biorbyt, Cambridge, UK), $\beta$-actin (rabbit polyclonal antibody 1:2000) (Cell Signaling Technology, Beverly, MA, USA) and its HRP-labeled secondary antibodies [33], followed by detection with an enhanced chemiluminescence reagent. Chemiluminescence of expressed bands were examined to confirm the linear range of the chemiluminescence signals, and the quantifications were performed using the densitometry tool in Image software v1.8.

\subsection{Molecular Docking}

\subsubsection{Protein Preparation}

Three-dimensional structures of proposed anti-apoptotic proteins, such as PTEN (PDBID-1D5R) and ZEB-2 (PDB-ID-2D8V), were retrieved from the RCSB PDB Protein Data Bank (https: / / www.rcsb.org/, accessed on 2 January 2022) to perform docking. To simulate, removal of confusing parameters such as water residue and free hydrogen atoms was undertaken. In addition, polar molecules were inserted to all protein structures applying the pymol tool and automated AutoDock tool. Autogrid was used to fit the protein molecule in gpf format and ligand protein complex in the center of the macromolecule with arrangement of $66 \%$ in each directional complex. Further active sites were examined in protein receptors using the web-based online tool Q-Site Finder. All ions, except for the binding site, and non-relevant crystallographic materials were detached. These active sites were chosen as the most favorable binding residues for the current docking simulation. 


\subsubsection{Ligand Preparation}

The structure of orientin was retrieved from the PubChem compound database of the National Center for Biotechnology Information (PubChem ID: 5281675). The downloaded structure was converted into PDB format using a freely available open-source tool, using pymol and AutoDock docking tools. In the edit tool, the orientin structure in PDB format was converted to pdbqt and selected the root of the ligand using AutoDock followed by Autogrid tools [34].

\subsection{Statistical Analysis}

Data are expressed as mean $\pm \mathrm{SD}$. The significant difference was analyzed by the Student's $t$-test. The multiple analyses were performed by one-way ANOVA using MS Office Excel. Comparisons between the means of various treatment groups were analyzed using the post hoc analysis of the Excel worksheet. A value of $p<0.05$ was considered to be statistically significant. Data are represented from at least three independent experiments.

\section{Results}

\subsection{Effect of Orientin on $\mathrm{CCl}_{4}$-Induced Liver Inflammation and Immune Dysfunction}

In this study, the protective effect of orientin on $\mathrm{CCl}_{4}$-induced liver inflammation in a mice model was investigated. As shown in Figure 1, induced liver inflammation was observed in disease groups, including the cirrhosis and inflammatory cellular infiltrations in the right lobe, and widespread hepatic fibrosis was observed as well. Moreover, the score of the liver injury was significantly higher in the $\mathrm{CCl}_{4}$ group compared to orientin alone and orientin with $\mathrm{CCl}_{4}$-treated groups. These orientin-treated disease mice distinctly alleviated the $\mathrm{CCl}_{4}$-induced liver damage and reduced infiltration of inflamed cells (Figure 2A). The serum liver functional markers ALT and AST of orientin-treated mice were quantified using the BioVision ELISA method [35]. Fibrosis and cirrhosis increased the aspartate aminotransferase (AST) and alanine aminotransferase (ALT) marker in mice (Figure 2B). Orientin attenuated the liver damage in $\mathrm{CCl}_{4}$-treated mice and evidently the ALT and AST markers were increased 1.91-fold in $\mathrm{CCl}_{4}$-treated mice, whereas the orientin-treated mice showed ALT/AST at a 1.23-fold ratio level compared to the control group (Figure 2B).

\subsection{Effect of Orientin on Expression of Inflammatory Markers in $\mathrm{CCl}_{4}$-Induced Liver Tissues}

Natural molecules play a major role in anti-inflammatory mechanisms in mice. As shown in Figure 3, orientin reduced pro-inflammatory markers such as TNF- $\alpha$, IL-6, IL-8, and IFN- $\gamma$, which were quantified in $\mathrm{CCl}_{4}$-induced mice. The $\mathrm{CCl}_{4}$-treated mice showed an elevated level of these markers compared to the control group and orientintreated group. Accordingly, the tissue lysate of orientin-treated mice showed significant reduction of TNF- $\alpha$ (from 421 to $241 \mathrm{pg} / \mathrm{mL}$ ), IL-6 (from 214 to $133 \mathrm{pg} / \mathrm{mL}$ ), IL-8 (from 800 to $580 \mathrm{pg} / \mathrm{mL}$ ), and IFN- $\gamma$ (from 228 to $175 \mathrm{pg} / \mathrm{mL}$ ) compared to the $\mathrm{CCl}_{4}$ inflammatory group (Figure $3 \mathrm{~A}-\mathrm{D}$ ). However, the orientin alone and orientin with $\mathrm{CCl}_{4}$-treated mice groups had strongly reduced inflammatory markers $(p<0.05)$. The fibrotic markers were potentially regulated by orientin, as it was regulated significantly in $\mathrm{CCl}_{4}$-induced liver tissues. The ZEB-2 mRNA was downregulated from 4.1-fold of the $\mathrm{CCl}_{4}$-induced condition to 2.2-fold of the orientin-treated condition. Similar findings were observed for PTEN mRNA and reduced from 9-fold to 4-fold (Figure 3E). The protein expression of ZEB-2 and PTEN were quantified in orientin-treated $\mathrm{CCl}_{4}$-induced mice and were downregulated from 2.7- and 2.5-fold of $\mathrm{CCl}_{4}$-induced inflammatory group to 1.6- and 1.9-fold in orientintreated groups. respectively (Figure $3 \mathrm{~F}, \mathrm{G}$ ). The orientin alone group showed insignificant expression of ZEB-2 and PTEN compared to the untreated control group. These results indicated that orientin significantly controlled the inflammatory and fibrotic markers in $\mathrm{CCl}_{4}$-induced mouse liver tissues. 
A

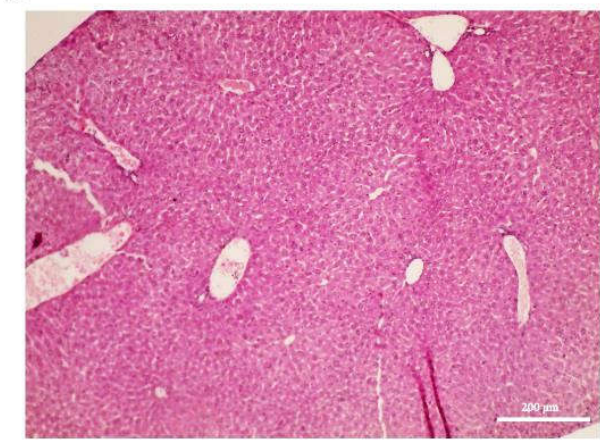

C

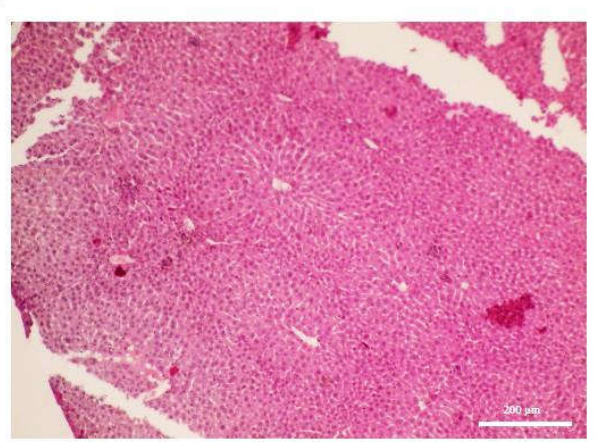

B

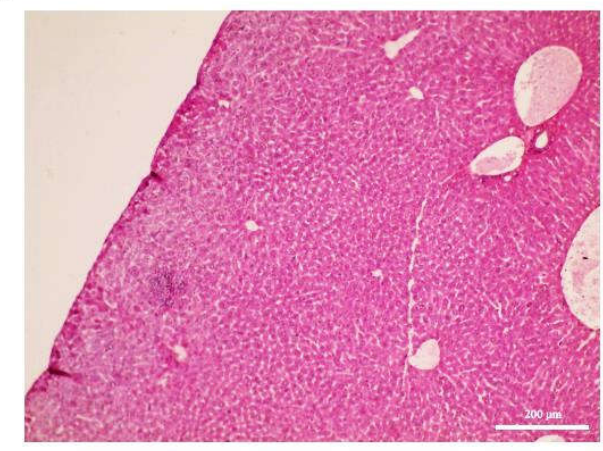

D

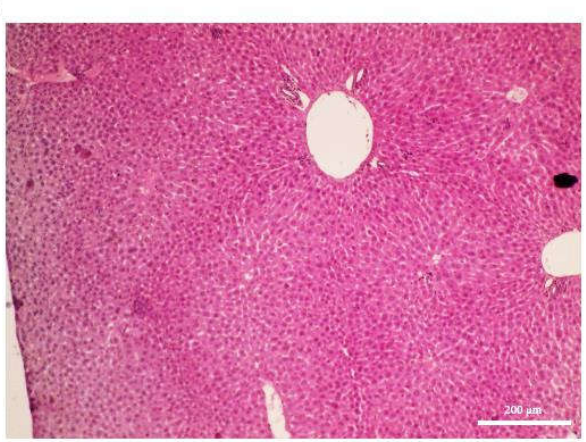

Figure 1. Morphological and histological evaluation of liver in mice. (A) Control group, (B) $\mathrm{CCl}_{4^{-}}$ treated group, (C) orientin (1 mg/kg)-treated group, and (D) $\mathrm{CCl}_{4}$ orientin $(1 \mathrm{mg} / \mathrm{kg})$-treated group. Magnification $\times 200$.
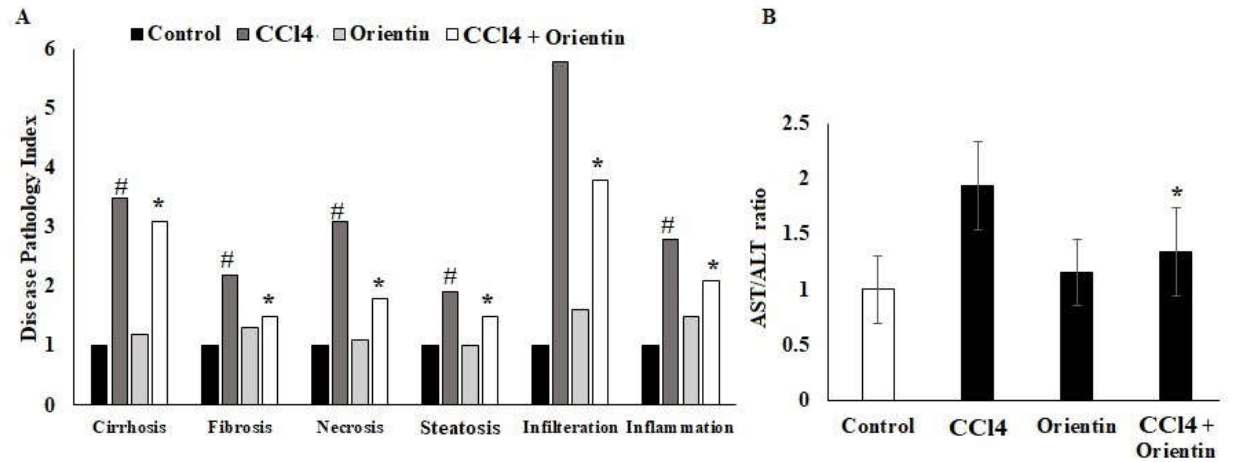

Figure 2. Effect of orientin on liver. (A) The disease pathology scores for liver injury. (B) Effect of orientin on $\mathrm{CCl}_{4}$-induced changes in hepatic functional markers of ALT activity and AST activity. Orientin-treated liver tissues were excised after the 7th day of ip injection and homogenate using ice cold PBS. All values are expressed as mean \pm SD. * Represents the significant comparison with the control. \# Represents the significant comparison with control and $\mathrm{CCl}_{4}$-induced groups.

\subsection{Docking of Orientin with Mouse PTEN and ZEB-2}

The docking study demonstrated the virtual interactions of orientin with phosphate membrane domains of mouse PTEN and stem cell membrane protein of mouse ZEB-2 using molecular docking software tools. The binding energy, ligand bonds, bond distance, and amino acid residue interaction were recorded in Tables 1 and 2 and Figure 4A,B. Orientin interacted with PTEN (-6.44) amino acid residue of the chain A domain (Figure 4A), such as asparagine, threonine, glycine, and arginine forming a hydrogen bond. Interestingly, the strong binding interactions were observed as a carbon hydrogen bond in asparagine and arginine residue of the PTEN protein. The cation and hydrophobic bonds were observed at tyrosine, proline, and arginine positions of 163 to 170 amino acid residues. Totally, ten different bonds were formed between orientin with mouse PTEN protein. The ZEB-2 protein interacted with orientin with a binding energy of $(-6.17)$ and, in total, 
six different amino acid residues in a position from 19 to 51 interacted with orientin chain $B$ and C. Orientin formed a sigma bond between ZEB-2 at a position of arginine 166 and confirmed the formation of an overlapped covalent bond (Figure 4B). These interactions demonstrated the involvement of orientin in signaling of hepatic cellular fibrosis and inflammatory markers.

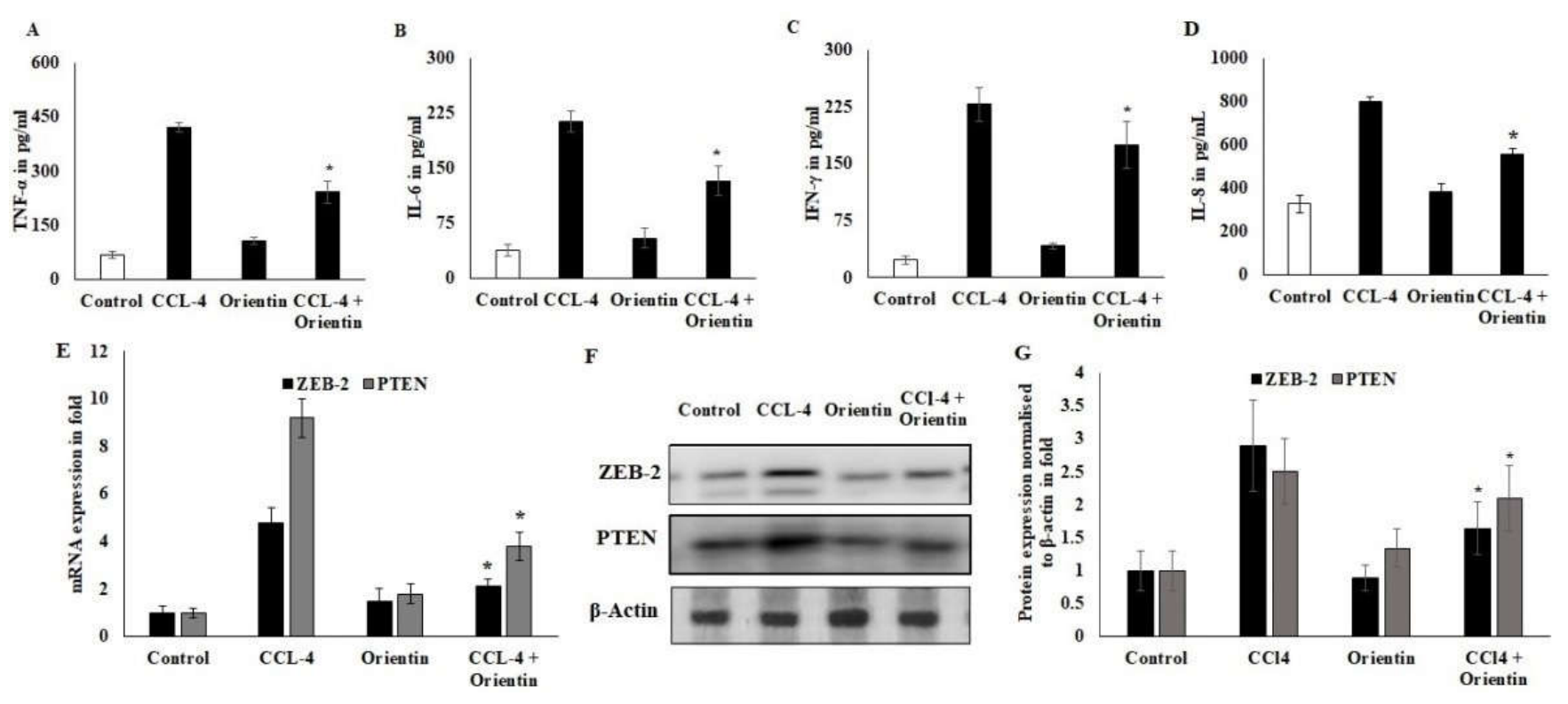

Figure 3. Effect of orientin on liver inflammatory markers. The $\mathrm{CCl}_{4}$-induced mice were administered for orientin $1 \mathrm{mg} / \mathrm{kg}$ body weight of mice for 7 days and liver tissues were excised. Liver homogenate was prepared using ice cold cell lysis buffer with $0.1 \%$ DTT. (A) The TNF- $\alpha$ was estimated using a Cayman ELISA kit. (B) IL-6 was estimated in liver lysate using a mouse Cayman ELISA kit. (C) IFN- $\gamma$ was estimated in liver lysate using a mouse Cayman ELISA kit. (D) IL-8 was estimated in liver lysate using a mouse Cayman ELISA kit. (E) mRNA expression of ZEB-2 and PTEN using real time PCR. $(F, G)$ Protein quantification of ZEB-2 and PTEN in $\mathrm{CCl}_{4}$-induced and $\mathrm{CCl}_{4}$ with orientin treatment using immunoblot-based techniques. (The data are represented as the mean \pm SD.) $p<0.05$.

* Represents the significant comparison with control and $\mathrm{CCl}_{4}$-induced groups.

Table 1. Interactions of orientin and ZEB2 receptor residues of target protein.

\begin{tabular}{|c|c|c|c|c|}
\hline $\begin{array}{l}\text { Binding } \\
\text { Energy }\end{array}$ & $\begin{array}{l}\text { Ligand } \\
\text { Efficiency }\end{array}$ & $\begin{array}{l}\text { Intermole } \\
\text { Energy }\end{array}$ & $\begin{array}{l}\text { Ligand Atoms } \\
\text { (Ring) }\end{array}$ & $\begin{array}{l}\text { Docked Amino Acid Residue } \\
\text { (Bond Length) }\end{array}$ \\
\hline-6.17 & -0.19 & -6.38 & $\begin{array}{l}\text { Conventional Hyd } \\
\text { Chain B-C3'-O } \\
\text { Chain B-C3'-OH } \\
\text { Chain B-C4'-OH } \\
\text { Chain C-C4-O } \\
\text { Chain A-C5-OH } \\
\text { C2-OH } \\
\text { C3-OH } \\
\text { C3-OH } \\
\text { Pi-Alkyl Hydroph } \\
\text { O } \\
\text { O } \\
\text { O } \\
\text { O } \\
\text { Pi-sigma bond: } \\
\text { O } \\
\text { O }\end{array}$ & 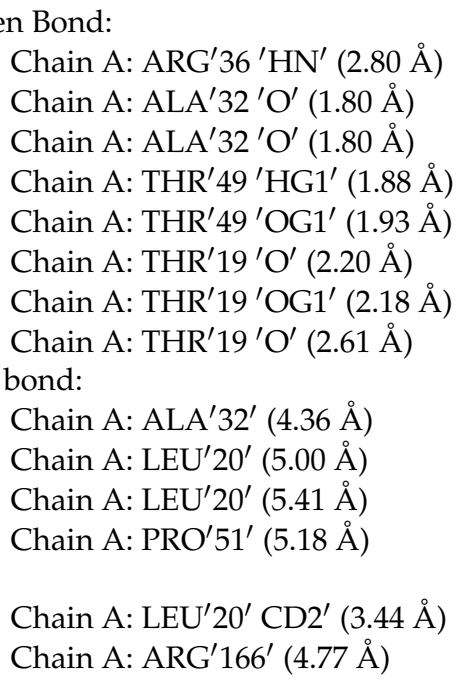 \\
\hline
\end{tabular}

ALA, alanine; ARG, arginine; LEU, leucine; ASN, asparagine; PRO, proline; THR, threonine. 
Table 2. Interactions of orientin and PTEN receptor residues of target protein.

\begin{tabular}{|c|c|c|c|c|}
\hline $\begin{array}{l}\text { Binding } \\
\text { Energy }\end{array}$ & $\begin{array}{l}\text { Ligand } \\
\text { Efficiency }\end{array}$ & $\begin{array}{l}\text { Intermole } \\
\text { Energy }\end{array}$ & $\begin{array}{l}\text { Ligand Atoms } \\
\text { (Ring) }\end{array}$ & $\begin{array}{l}\text { Docked Amino Acid Residue } \\
\text { (Bond Length) }\end{array}$ \\
\hline \multirow{3}{*}{-6.44} & \multirow{3}{*}{-0.2} & \multirow{3}{*}{-6.44} & $\begin{array}{l}\text {-Conventional Hydrog } \\
\text { Chain B-C4'-O } \\
\text { Chain B-C4'-OH } \\
\text { Chain B-C3'-OH } \\
\text { Chain } \mathrm{C}-\mathrm{C} 4^{\prime}-\mathrm{O} \\
\text { Chain } \mathrm{C}-\mathrm{C} 4^{\prime}-\mathrm{O} \\
\text { C4-OH }\end{array}$ & $\begin{array}{l}\text { Cen Bond: } \\
\text { Chain A: ASN'323 'HD22' (1.92 } \AA) \\
\text { Chain A: THR' } 161^{\prime} \mathrm{O}^{\prime}(1.83 \AA) \\
\text { Chain A: THR' } 161^{\prime} \mathrm{O}^{\prime}(2.24 \AA) \\
\text { Chain A: GLN'143 'HE22' }(1.90 \AA) \\
\text { Chain A: GLN'143 'HE21' (2.44 } \mathrm{A}) \\
\text { Chain A: ARG'167 'HH12' (2.35 })\end{array}$ \\
\hline & & & $\begin{array}{l}\text {-Carbon Hydrogen Bor } \\
\text { C } \\
\text { C }\end{array}$ & $\begin{array}{l}\text { nd } \\
\text { Chain A: ASP'318'OD2' (3.19 } \AA) \\
\text { Chain A: ARG'167'CD' (2.90 })\end{array}$ \\
\hline & & & $\begin{array}{l}\text {-Pi-Alkyl Hydrophobic } \\
\text { O } \\
\text { O } \\
\text {-Pi-Pi T-shaped bond: } \\
\text { O } \\
\text { O } \\
\text {-Pi-cation bond: } \\
\text { O }\end{array}$ & $\begin{array}{l}\text { bond: } \\
\text { Chain A: TRY'170' (5.65 } \AA) \\
\text { Chain A: TRY'170' (4.81 }) \\
\text { Chain A: } \text { PRO'}^{\prime} 163^{\prime}(4.56 \AA) \\
\text { Chain A: } \text { ARG }^{\prime} 166^{\prime}(4.77 \AA) \\
\text { Chain A: ARG' } 166^{\prime} \mathrm{NH} 2^{\prime}(4.35 \AA)\end{array}$ \\
\hline
\end{tabular}

ARG, arginine; ASN, asparagine; ASP, aspartic acid; GLN, glutamine; PRO, proline; TRY, tyrosine.

\subsection{Effect of Orientin on LPS-Induced Inflammation in Hepatic Stellate Cells}

Orientin controlled cell proliferation, nitric oxide, iNOS, and inflammatory structural stress in LPS-induced inflammatory mouse-derived HSCs (Figure 5A-D). As shown in Figure 5A, orientin significantly inhibited the LPS $10 \mathrm{ng} / \mathrm{mL}$-induced proliferation in mice-derived HSCs. The LPS-challenged cells were exposed to orientin in concentration $(10$ to $80 \mu \mathrm{M})$ for $24 \mathrm{~h}$ and cell proliferation was quantified. The cell proliferation was inhibited gradually based on the dose of orientin concentration and it was found that 20 and $40 \mu \mathrm{M}$ significantly controlled the proliferation and was non-toxic to murine hepatic cells. Thus, we selected an orientin concentration of $30 \mu \mathrm{M}$ for our further ex vivo studies to evaluate the effect of orientin on LPS-induced HSC inflammation. LPS statistically stimulated HSC proliferation (Figure 5A), indicating that LPS could increase the functional metabolic and inflammatory markers of HSCs. The treatment of orientin reduces LPSrelated cell functioning markers. The effect of orientin on anti-inflammatory markers in LPS-activated HSCs was evaluated; we treated murine HSCs with either LPS alone, or LPS with orientin concentrations of $30 \mu \mathrm{M}$. Nitric oxide (nitrate $\mu \mathrm{M}$ ) was used to determine proinflammatory activity of the host cells. Orientin significantly decreased LPS-induced nitric oxide from 35 to $27 \mu \mathrm{M}$, whereas orientin alone showed a similar nitric oxide concentration compared to untreated control HSCs (Figure 5B). LPS-stimulated expression of iNOS was determined by immunoblot. Orientin alleviated iNOS expression in the LPS-induced group (2.2-fold) comparatively to the LPS alone group (4.3-fold) $(p<0.05)$ (Figure 5C,D). These results were co-related with HSC differentiation and maturation in LPS-induced conditions (Figure 6).

\subsection{Effect of Orientin on Hepatic Fibrotic Signaling Markers ZEB-2, PTEN, and TNF- $\alpha$}

Orientin regulated the fibrotic markers in HSCs. The mRNA and protein expression of ZEB-2, PTEN, and TNF- $\alpha$ were quantified in orientin-treated LPS-challenged HSCs (Figure 7). The ZEB-2 mRNA was downregulated from 4.4-fold of the LPS-induced condition to 3.1-fold of the orientin-treated condition (Figure 7A). Similar findings were observed in protein expression of ZEB-2 and reduced from 6.2-fold to 2.4-fold (Figure 7B,C). This indicates orientin controlled the mesenchymal modification of HSCs and inhibited the hepatic inflammation. HSC activator PTEN was inhibited by orientin treatment. The mRNA and protein expression of PTEN was significantly downregulated in orientin-treated HSCs. 
Orientin inhibited the LPS-induced PTEN 3.4-fold of mRNA and 2.5-fold of protein expression into 2.6-fold and 1.9-fold of mRNA and protein, respectively (Figure 7A-C). The inflammatory marker TNF- $\alpha$ was significantly inhibited by orientin treatment and it was downregulated from 4.9-fold of LPS-induced mRNA to 3.1-fold of mRNA. Orientin treatment of LPS-treated HSC led to a decrease of TNF $\alpha$ protein levels (2.8-fold), when compared to HSCs treated only with LPS (4.5-fold) (Figure 7A-C). The ZEB-2 expression was increased in the orientin alone treated group compared to the untreated control group (Figure 7B,C).
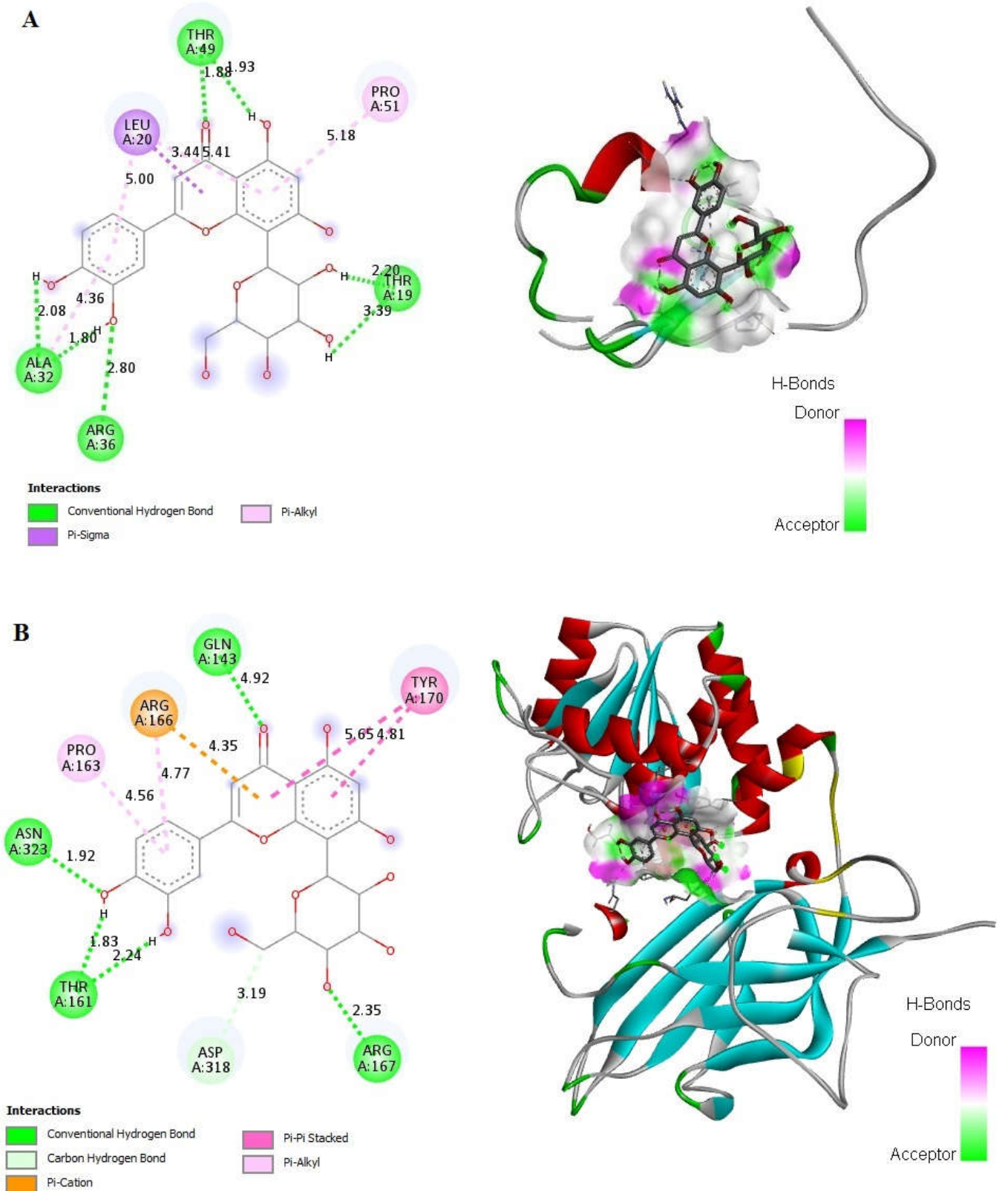

Figure 4. In silico docking of orientin (CID: 5281675) and (A) mouse PTEN (PDB-ID-1D5R) and (B) ZEB-2 (PDB-ID-2D8V) proteins binding analysis. Computational binding was performed using AutoDock software to demonstrate the illustration of interactions in the hydrophobic bond and other polar bonds of PTEN and ZEB-2. It shows the amino acid residue analysis of the interacted bond and its length, together with the binding pocket of ligand-receptor interactions. 
A

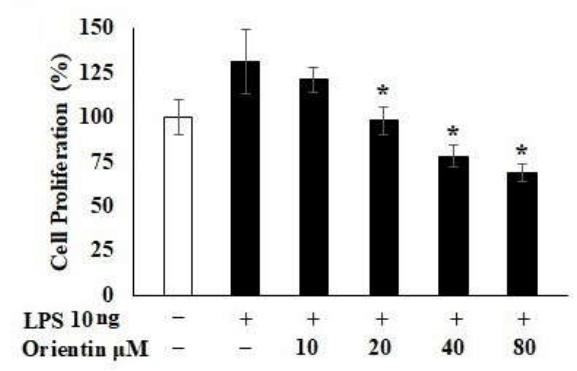

C

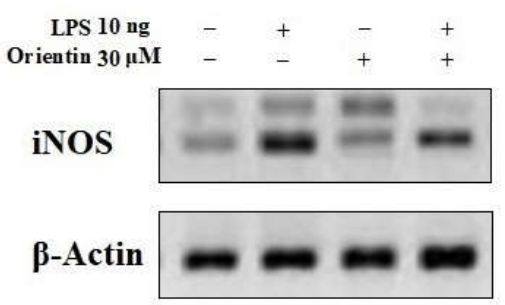

B

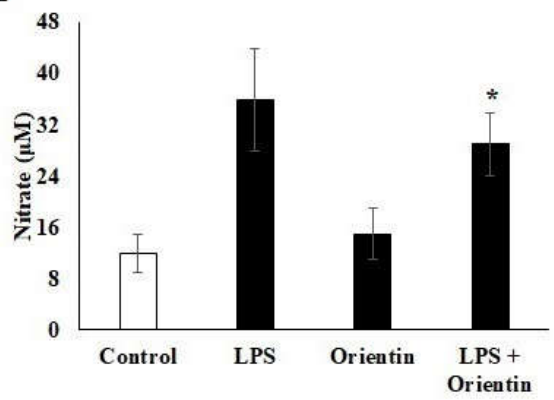

D

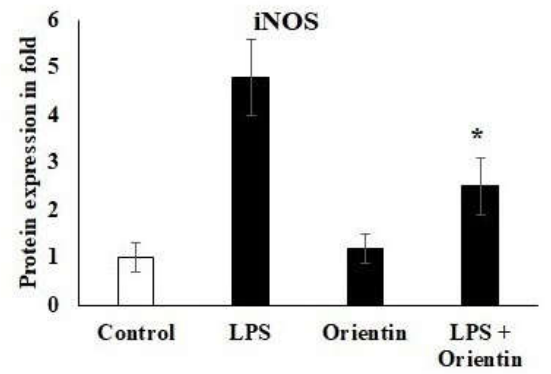

Figure 5. Effect of orientin on LPS-induced inflammatory HSCs. Naïve mouse-derived HSCs were isolated and cultured in an adherent-coated 12-well plate. Cultured cells were stimulated with LPS $10 \mathrm{ng}$ for $2 \mathrm{~h}$ and orientin was treated for $12 \mathrm{~h}$. Treated cells were evaluated for cell proliferation, nitrate quantification, and iNOS protein. (A) Cell proliferation of LPS-stimulated HSCs and LPS with orientin-treated cells were quantified using SRB assay. (B) Nitric oxide level as nitrate $(\mu \mathrm{M})$ in LPS-stimulated and orientin-treated HSCs. (C,D) iNOS protein quantification using immunoblot. Values are expressed as three independent experiments and all values are expressed as mean $\pm \mathrm{SD}$.

* Represents the significant comparison with control and LPS-induced groups.

A

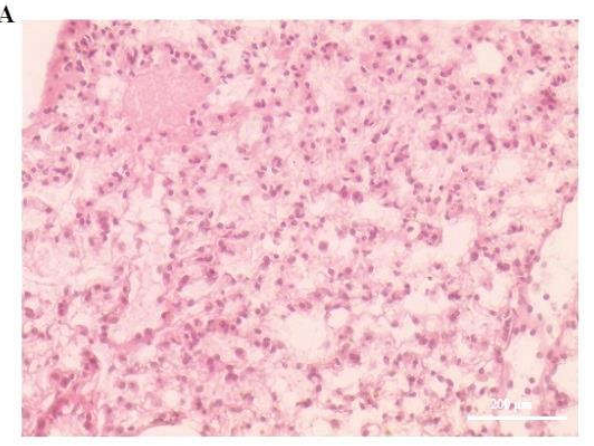

C

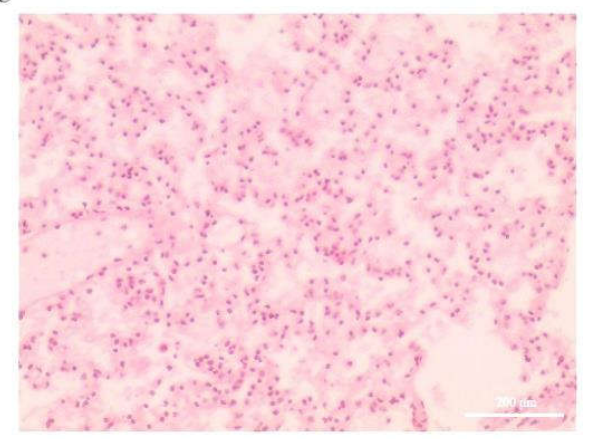

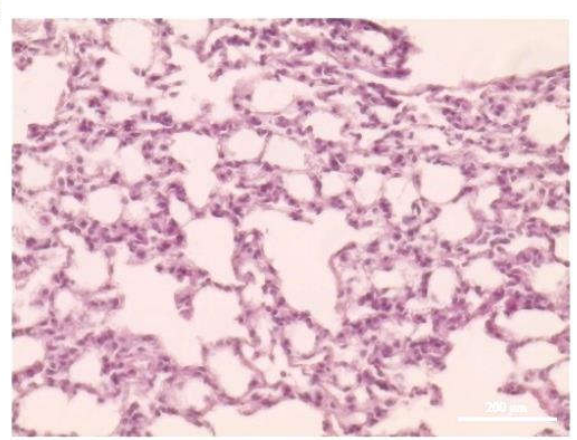

D

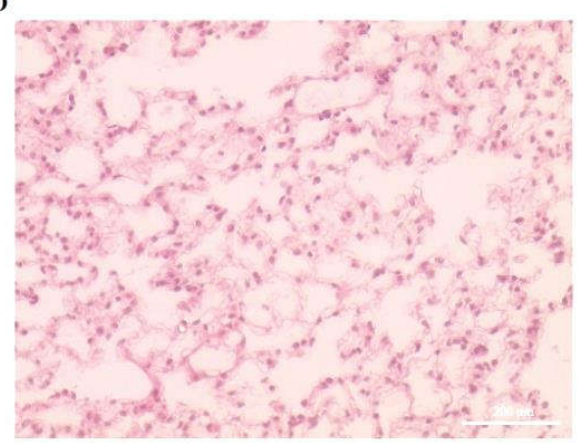

Figure 6. Effect of orientin on LPS-induced inflammatory HSCs. Naïve mouse-derived HSCs were isolated and cultured in an adherent-coated 12-well plate. Cultured cells were stimulated with LPS $10 \mathrm{ng}$ for $2 \mathrm{~h}$ and treated with orientin $(30 \mu \mathrm{M})$ for $12 \mathrm{~h}$. (A) Control group, (B) LPS-treated group, (C) orientin $(30 \mu \mathrm{M})$-treated group, and (D) LPS and orientin $(30 \mu \mathrm{M})$-treated group. 
A
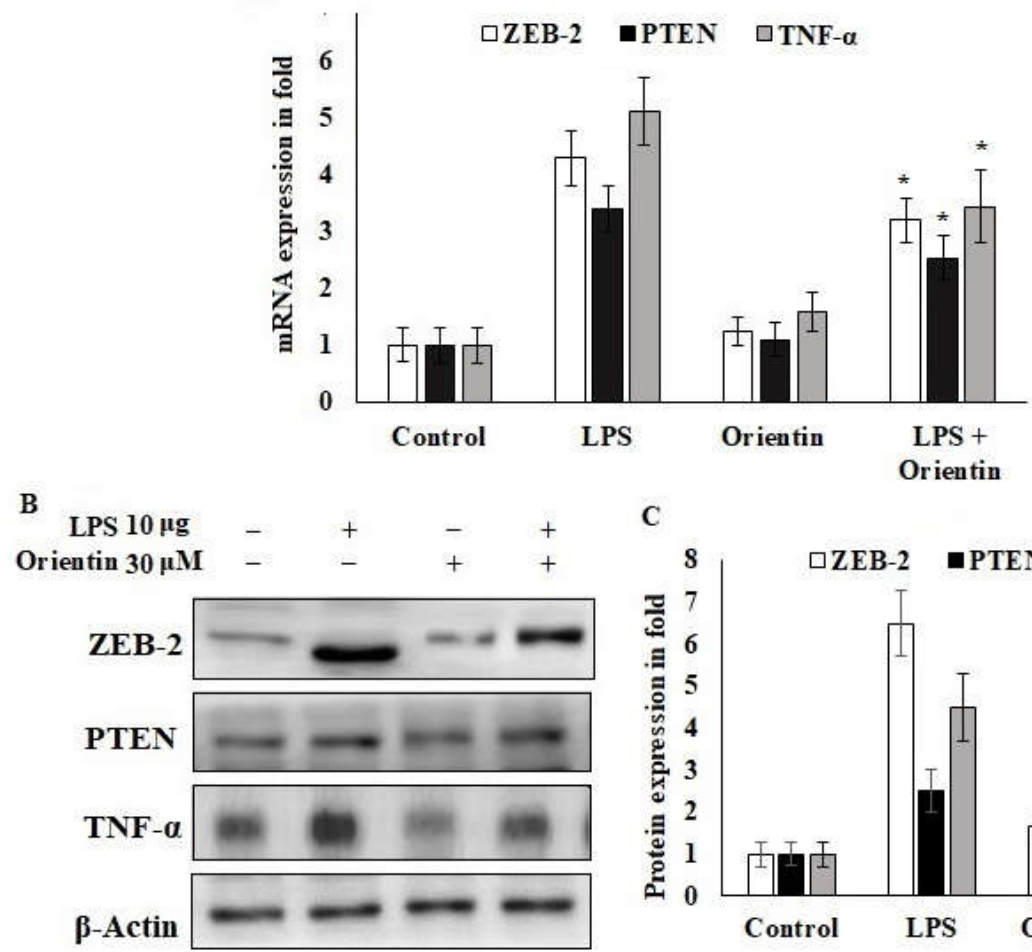

C

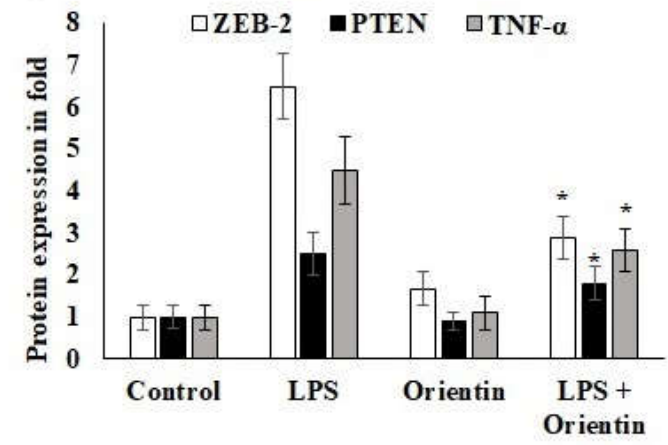

Figure 7. Effect of orientin on hepatic fibrotic signaling markers ZEB-2 and PTEN. Naïve mousederived HSCs were stimulated with LPS $10 \mathrm{ng}$ for $2 \mathrm{~h}$ and treated for $12 \mathrm{~h}$ with orientin $(30 \mu \mathrm{M})$. Treated cells were evaluated for ZEB-2, PTEN, and TNF- $\alpha$ mRNA and protein were quantified. (A) mRNA quantification of ZEB-2, PTEN, and TNF- $\alpha$ in LPS-stimulated HSCs and LPS with orientintreated cells was undertaken using SYBR green-based real time PCR assay. (B,C) Protein quantification of ZEB-2, PTEN, and TNF- $\alpha$ in LPS-stimulated HSCs and LPS with orientin (30 $\mu \mathrm{M})$-treated cells using immunoblot-based techniques. Values are expressed as three independent experiments and all values are expressed as mean $\pm \mathrm{SD}$. * Represents the significant comparison with the control and LPS-induced groups.

\section{Discussion}

The need of for herbal supplements has been increased because of their merits to control oxidative hepatic damage [36]. Hepatotoxicity induced by $\mathrm{CCl}_{4}$ leads to liver injury, hepatic cell death, and activation of cell necrotic pathways [37]. The long-term exposure of $\mathrm{CCl}_{4}$ leads to chronic liver damage and hepatic carcinoma. Recent strategies focused on usage of plant-derived flavonoids, such as luteolin, as hepato-protective, anti-oxidative, and anti-inflammatory agents [38]. In this study, the effect of orientin on liver protection and anti-inflammatory mechanisms in liver tissues in mice were examined. The pathological score and disease index were significantly reduced by orientin treatment in a concentration of $1 \mathrm{mg} / \mathrm{kg}$ bw of mouse. The pathophysiology of liver tissue showed that orientin significantly reduced cirrhosis, necrotic cellular morphology, and inflamed infiltration in hepatic tissue (Figure 1). Some studies showed that the flavonoids improve the hepatic cellular architecture from $\mathrm{CCl}_{4}$-induced hepatic damage [39,40]. Liver metabolic enzymes play a major role in detoxification, fibrotic steatosis, and inflammatory modifications of the host. Several studies showed plant flavonoids potentially augmented the AST/ALT level in a $\mathrm{CCl}_{4}$-induced mouse model [41-43]. In this present study, AST/ALT was potentially reduced by orientin $1 \mathrm{mg} / \mathrm{kg}$ bw compared to the $\mathrm{CCl}_{4}$-induced mice group. The orientin alone treated mice showed similar levels compared to untreated groups (Figure 2A,B). These data are concurrent with the reported modulatory action of extracts of orientin using acetaminophen-induced liver damage in a mice model showing boosted ALT/AST levels, maintaining a normal liver structure, and moderate activity against the iNOS. The current 
study demonstrated detailed mechanisms of orientin towards reduction of TNF- $\alpha$, IL-6, IL-8, and IFN- $\gamma$ in a CCl $\mathrm{Cl}_{4}$-induced mice model and downregulation of ZEB-2 and PTEN fibrotic markers in LPS-induced murine HSCs [44-46].

The inflammatory cytokines are key players of fibrotic mediators and are associated with worse prognosis of the inflammatory liver disease [26]. The $\mathrm{CCl}_{4}$ administration led to a rise in the level of pro-inflammatory mediators such as TNF- $\alpha$, IL-6, IL-8, and IFN- $\gamma$ (Figure 3A-D). However, the orientin treatment showed marked reduction in the inflammatory cytokines compared to the $\mathrm{CCl}_{4}$ control group. Some previous reports showed the similar ameliorative effect of naringenin and orientin on TNF- $\alpha$, IL-6, and iNOS in mice models $[15,44-47]$. The liver fibrotic markers, ZEB-2 and PTEN, were upregulated in the $\mathrm{CCl}_{4}$-treated group, whereas orientin potentially reduced the expression of ZEB2 and reached 1.7-fold from a 2.8-fold expression (Figure 3E-G). The PTEN expression was downregulated in the orientin treatment compared to the $\mathrm{CCl}_{4}$ treatment. Protein expression was reduced to $13 \%$ compared to the $\mathrm{CCl}_{4}$ group (Figure 3G). The virtual binding of orientin with ZEB-2 and PTEN was achieved and potent binding was observed (Figure 4A,B). The formation of pi-Alkyl hydrophobic bonds between orientin and PTEN changed the structural confirmation and led to less potent receptor molecules. The amino acid residues interacting with orientin from residue 160 to 167 played a major role in coupled complex regulations (Table 1). Regarding the ZEB-2 interaction with orientin, it formed a sigma bond between ZEB-2 at the position of residue 166 and confirmed the formation of an overlapped covalent bond. The coupled complex formations demonstrated the involvement of orientin, with ZEB-2 downregulating the signaling process of protein and controlling the fibrotic formation in intracellular regulatory elements (Table 2).

HSCs play major role in liver cirrhosis and lipid metabolism [48]. Previous studies evidenced that inhibition of HSC proliferation led to prevention of liver injury and fibrosis [49-51]. Therefore, natural molecules are focused on liver protection and host health. In this study, we first examined the effect of orientin on LPS-induced murine HSCs and estimated the ZEB-2 and PTEN fibrotic markers. The results indicated that orientin treatment caused cell protection from LPS-induced hepatotoxicity (Figures 5 and 6A). The inflammatory nitric oxide marker was potentially reduced (from 36 to $27 \mu \mathrm{M}$ ) by orientin in LPS-induced HSCs (Figure 6B), indicating the negative progression of fibrosis in LPSinduced inflamed HSCs. The induced nitric oxide synthase is a key regulator of nitric oxide production and its signaling pathways [52]. The orientin treatment reduced the LPS-induced iNOS expression in HSCs and consequently confirmed the reduction of nitric oxide release (Figure 6C,D).

Fibrotic markers such as ZEB-2, PTEN, and TNF- $\alpha$ played a key role in hepatic fibrosis and mesenchymal transition of liver tissues [53-55]. In this study, transcripts and protein expressions of these markers were significantly reduced by orientin, which consequently control the transition of HSCs from mesenchymal to fibroblastic architecture. Significant downregulation of ZEB-2, PTEN, and TNF- $\alpha$ in the orientin treatment group confirmed that this phytochemical is able to inhibit the LPS-induced fibrotic process (Figure 7A-C).

\section{Conclusions}

The present study demonstrated that orientin significantly diminished liver cirrhosis, inflamed infiltration, and boosted AST/ALT levels in $\mathrm{CCl}_{4}$-induced mice. In addition, the levels of inflammatory markers (TNF- $\alpha$, IL-6, IL-8, and IFN- $\gamma$ ) and fibrotic markers (ZEB-2 and PTEN) were decreased by orientin treatment in $\mathrm{CCl}_{4}$-induced liver toxicity. On the other hand, significant downregulation of ZEB-2, PTEN, and TNF- $\alpha$ was demonstrated in orientin treatment against LPS-induced HSC fibrotic processes. Orientin also showed reduction of iNOS expression and nitric oxide release in HSCs of the LPS-induced fibrotic cells. The results were supported with virtual binding studies. In conclusion, transcripts and protein expression of inflammatory, as well as fibrotic, markers were significantly attenuated by orientin in HSCs and subsequently control the transition of HSCs from mesenchymal to fibroblastic fashion. 


\begin{abstract}
Author Contributions: H.E.K.: conceptualization, funding acquisition, methodology, writingreview and editing, writing-original draft preparation and supervision; H.-I.M.I.: formal analysis, methodology, validation, software, writing — review and editing, writing-original draft preparation; K.A.E.-F.: writing-review and editing; S.H.A.: writing-review and editing; M.A.M.: validation, writing-review and editing. All authors have read and agreed to the published version of the manuscript.
\end{abstract}

Funding: This project was funded by the Deanship of Scientific Research (DSR), King Faisal University, Al-Ahsa, Saudi Arabia (Nasher Track, project No. 216092).

Institutional Review Board Statement: The study was conducted in accordance with the Declaration of Helsinki and approved by the Ethics Committee of King Faisal University (KFU-REC-2022-JANEA000401).

\title{
Informed Consent Statement: Not applicable.
}

Data Availability Statement: Not applicable.

Acknowledgments: The authors acknowledge with thanks the Deanship of Scientific Research (DSR), King Faisal University, Al-Ahsa, Saudi Arabia (Nasher Track, project No. 216092).

Conflicts of Interest: The authors declare no conflict of interest is associated with this work.

\section{References}

1. Del Campo, J.A.; Gallego, P.; Grande, L. Role of inflammatory response in liver diseases: Therapeutic strategies. World J. Hepatol. 2018, 10, 1. [CrossRef] [PubMed]

2. Chalasani, N.; Younossi, Z.; Lavine, J.E.; Diehl, A.M.; Brunt, E.M.; Cusi, K.; Charlton, M.; Sanyal, A.J. The diagnosis and management of non-alcoholic fatty liver disease: Practice Guideline by the American Association for the Study of Liver Diseases, American College of Gastroenterology, and the American Gastroenterological Association. Hepatology 2012, 55, $2005-2023$. [CrossRef] [PubMed]

3. Calvente, C.J.; Tameda, M.; Johnson, C.D.; Del Pilar, H.; Lin, Y.C.; Adronikou, N.; Du Jeu, X.D.M.; Llorente, C.; Boyer, J.; Feldstein, A.E. Neutrophils contribute to spontaneous resolution of liver inflammation and fibrosis via microRNA-223. J. Clin. Investig. 2019, 129, 4091-4109. [CrossRef] [PubMed]

4. Koyama, Y.; Brenner, D.A. Liver inflammation and fibrosis. J. Clin. Investig. 2017, 127, 55-64. [PubMed]

5. Nallagangula, K.S.; Nagaraj, S.K.; Venkataswamy, L.; Chandrappa, M. Liver fibrosis: A compilation on the biomarkers status and their significance during disease progression. Future Sci. OA 2017, 4, FSO250.

6. De Haan, W.; Dheedene, W.; Apelt, K.; Décombas-Deschamps, S.; Vinckier, S.; Verhulst, S.; Conidi, A.; Deffieux, T.; Staring, M.W.; Vandervoort, P. Endothelial Zeb2 preserves the hepatic angioarchitecture and protects against liver fibrosis. Cardiovasc. Res. 2021, 1-14. [CrossRef]

7. Jin, H.; Li, C.; Dong, P.; Huang, J.; Yu, J.; Zheng, J. Circular RNA cMTO1 promotes PTEN expression through sponging miR-181b-5p in liver fibrosis. Front. Cell. Dev. Biol. 2020, 8, 714. [CrossRef]

8. Wandrer, F.; Liebig, S.; Marhenke, S.; Vogel, A.; John, K.; Manns, M.P.; Teufel, A.; Itzel, T.; Longerich, T.; Maier, O. TNF-Receptor-1 inhibition reduces liver steatosis, hepatocellular injury and fibrosis in NAFLD mice. Cell Death Dis. 2020, 11, 1-9. [CrossRef]

9. Prystupa, A.; Kiciński, P.; Sak, J.; Boguszewska-Czubara, A.; Toruń-Jurkowska, A.; Załuska, W. Proinflammatory cytokines (IL-1 $\alpha$, IL-6) and hepatocyte growth factor in patients with alcoholic liver cirrhosis. Gastroenterol. Res. Pract. 2015, 2015, 1-7. [CrossRef]

10. Attallah, A.M.; El-Far, M.; Zahran, F.; Shiha, G.E.; Farid, K.; Omran, M.M.; Abdelrazek, M.A.; Attallah, A.A.; El-Beh, A.A.; El-Hosiny, R.M. Interferon-gamma is associated with hepatic dysfunction in fibrosis, cirrhosis, and hepatocellular carcinoma. $J$. Immunoass. Immunochem. 2016, 37, 597-610. [CrossRef]

11. Gonzalez-Gallego, J.; Sánchez-Campos, S.; Tunon, M. Anti-inflammatory properties of dietary flavonoids. Nutr. Hosp. 2007, 22, 287-293. [PubMed]

12. Ullah, A.; Munir, S.; Badshah, S.L.; Khan, N.; Ghani, L.; Poulson, B.G.; Emwas, A.-H.; Jaremko, M. Important flavonoids and their role as a therapeutic agent. Molecules 2020, 25, 5243. [CrossRef] [PubMed]

13. Ciumărnean, L.; Milaciu, M.V.; Runcan, O.; Vesa, Ș.C.; Răchișan, A.L.; Negrean, V.; Perné, M.-G.; Donca, V.I.; Alexescu, T.-G.; Para, I. The effects of flavonoids in cardiovascular diseases. Molecules 2020, 25, 4320. [CrossRef] [PubMed]

14. Ginwala, R.; Bhavsar, R.; Chigbu, D.G.I.; Jain, P.; Khan, Z.K. Potential role of flavonoids in treating chronic inflammatory diseases with a special focus on the anti-inflammatory activity of apigenin. Antioxidants 2019, 8, 35. [CrossRef]

15. Hernández-Aquino, E.; Muriel, P. Beneficial effects of naringenin in liver diseases: Molecular mechanisms. World J. Gastroenterol. 2018, 24, 1679. [CrossRef]

16. Raso, G.M.; Meli, R.; Di Carlo, G.; Pacilio, M.; Di Carlo, R. Inhibition of inducible nitric oxide synthase and cyclooxygenase-2 expression by flavonoids in macrophage J774A. 1. Life Sci. 2001, 68, 921-931. [CrossRef]

17. Gülçin, I. Antioxidant activity of food constituents: An overview. Arch. Toxicol. 2012, 86, 345-391. [CrossRef]

18. Gulcin, İ. Antioxidants and antioxidant methods: An updated overview. Arch. Toxicol. 2020, 94, 651-715. [CrossRef] 
19. Lee, W.; Ku, S.-K.; Bae, J.-S. Vascular barrier protective effects of orientin and isoorientin in LPS-induced inflammation in vitro and in vivo. Vascul. Pharmacol. 2014, 62, 3-14. [CrossRef]

20. Dantas-Medeiros, R.; Furtado, A.A.; Zanatta, A.C.; Torres-Rêgo, M.; Lourenço, E.M.G.; Alves, J.S.F.; Galinari, É.; de Oliveira Rocha, H.A.; Guerra, G.C.B.; Vilegas, W. Mass spectrometry characterization of Commiphora leptophloeos leaf extract and preclinical evaluation of toxicity and anti-inflammatory potential effect. J. Ethnopharmacol. 2021, 264, 113229. [CrossRef]

21. Lam, K.Y.; Ling, A.P.K.; Koh, R.Y.; Wong, Y.P.; Say, Y.H. A review on medicinal properties of orientin. Adv. Pharmacol. Sci. 2016, 2016, 1-9. [CrossRef]

22. Batool, R.; Kalsoom, A.; Akbar, I.; Arshad, N.; Jamil, N. Antilisterial Effect of Rosa damascena and Nymphaea alba in Mus musculus. Biomed. Res. Int. 2018, 2018, 1-9.

23. Abtulov, M.; Valcheva-Kuzmanova, S. Flavonoids and the liver-A review. Scr. Sci. Pharm. 2021, 8, 7-16.

24. Wu, Y.; He, Y.; Wang, R.; Zhao, X. Preventive Effect of Flavonoid Extract from the Peel of Gonggan (Citrus reticulata Blanco Var. Gonggan) on $\mathrm{CCl}_{4}$-Induced Acute Liver Injury in Mice. J. Inflamm. Res. 2021, 14, 5111. [CrossRef] [PubMed]

25. Ajuwon, O.R.; Oguntibeju, O.O.; Marnewick, J.L. Amelioration of lipopolysaccharide-induced liver injury by aqueous rooibos (Aspalathus linearis) extract via inhibition of pro-inflammatory cytokines and oxidative stress. BMC Complement. Altern. Med. 2014, 14, 1-12. [CrossRef] [PubMed]

26. Ho, C.-H.; Huang, J.-H.; Sun, M.-S.; Tzeng, I.; Hsu, Y.-C.; Kuo, C.-Y. Wild bitter melon extract regulates LPS-induced hepatic stellate cell activation, inflammation, endoplasmic reticulum stress, and ferroptosis. Evid. Based Complement. Alternat. Med. 2021, 2021, 1-11. [CrossRef] [PubMed]

27. Rong, X.; Xu, J.; Jiang, Y.; Li, F.; Chen, Y.; Dou, Q.P.; Li, D. Citrus peel flavonoid nobiletin alleviates lipopolysaccharide-induced inflammation by activating IL-6/STAT3/FOXO3a-mediated autophagy. Food Funct. 2021, 12, 1305-1317. [CrossRef]

28. Yan, G.; Chen, L.; Wang, H.; Wu, S.; Li, S.; Wang, X. Baicalin inhibits LPS-induced inflammation in RAW264. 7 cells through miR-181b/HMGB1/TRL4/NF-kB pathway. Am. J. Transl. Res. 2021, 13, 10127.

29. Zamani-Garmsiri, F.; Emamgholipour, S.; Rahmani Fard, S.; Ghasempour, G.; Jahangard Ahvazi, R.; Meshkani, R. Polyphenols: Potential anti-inflammatory agents for treatment of metabolic disorders. Phytother. Res. 2021, 36, 415-432. [CrossRef]

30. Mederacke, I.; Dapito, D.H.; Affò, S.; Uchinami, H.; Schwabe, R.F. High-yield and high-purity isolation of hepatic stellate cells from normal and fibrotic mouse livers. Nat. Protoc. 2015, 10, 305-315. [CrossRef]

31. Goshi, E.; Zhou, G.; He, Q. Nitric oxide detection methods in vitro and in vivo. Med. Gas Res. 2019, 9, 192. [CrossRef]

32. Khalil, H.E.; Ibrahim, H.-I.M.; Ahmed, E.A.; Emeka, P.M.; Alhaider, I.A. Orientin, a Bio-Flavonoid from Trigonella hamosa L., Regulates COX-2/PGE-2 in A549 Cell Lines via miR-26b and miR-146a. Pharmaceuticals 2022, 15, 154. [CrossRef] [PubMed]

33. Khalil, H.E.; Ibrahim, H.-I.M.; Darrag, H.M.; Matsunami, K. Insight into Analysis of Essential Oil from Anisosciadium lanatum Boiss.-Chemical Composition, Molecular Docking, and Mitigation of Hepg2 Cancer Cells through Apoptotic Markers. Plants 2022, 11, 66. [CrossRef] [PubMed]

34. Thirugnanasambantham, K.; Muralidaran, S.; Mandal, A.K.A. Molecular cloning, computational and expression analysis of anthocyanidin reductase in tea (Camellia sinensis). Appl. Biochem. Biotechnol. 2014, 174, 130-145. [CrossRef] [PubMed]

35. Takasu, C.; Vaziri, N.D.; Li, S.; Robles, L.; Vo, K.; Takasu, M.; Pham, C.; Farzaneh, S.H.; Shimada, M.; Stamos, M.J. Treatment with dimethyl fumarate ameliorates liver ischemia/reperfusion injury. World J. Gastroenterol. 2017, 23, 4508. [CrossRef] [PubMed]

36. Dutta, S.; Chakraborty, A.K.; Dey, P.; Kar, P.; Guha, P.; Sen, S.; Kumar, A.; Sen, A.; Chaudhuri, T.K. Amelioration of CCl ${ }_{4}$ induced liver injury in swiss albino mice by antioxidant rich leaf extract of Croton bonplandianus Baill. PLoS ONE 2018, 13, e0196411. [CrossRef] [PubMed]

37. Chang, S.N.; Kim, S.H.; Dey, D.K.; Park, S.M.; Nasif, O.; Bajpai, V.K.; Kang, S.C.; Lee, J.; Park, J.G. 5-O-Demethylnobiletin alleviates $\mathrm{CCl}_{4}$-Induced acute liver injury by equilibrating ROS-mediated apoptosis and autophagy induction. Int. J. Mol. Sci. 2021, 22, 1083. [CrossRef]

38. Akindele, A.J.; Oludadepo, G.O.; Amagon, K.I.; Singh, D.; Osiagwu, D.D. Protective effect of carvedilol alone and coadministered with diltiazem and prednisolone on doxorubicin and 5-fluorouracil-induced hepatotoxicity and nephrotoxicity in rats. Pharmacol. Res. Perspect. 2018, 6, e00381. [CrossRef]

39. Gharbia, S.; Balta, C.; Herman, H.; Rosu, M.; Váradi, J.; Bácskay, I.; Vecsernyés, M.; Gyöngyösi, S.; Fenyvesi, F.; Voicu, S.N. Enhancement of Silymarin Anti-fibrotic Effects by Complexation With Hydroxypropyl (HPBCD) and Randomly Methylated (RAMEB) $\beta$-Cyclodextrins in a Mouse Model of Liver Fibrosis. Front. Pharmacol. 2018, 9, 883. [CrossRef]

40. Owumi, S.; Lewu, D.; Arunsi, U.; Oyelere, A. Luteolin attenuates doxorubicin-induced derangements of liver and kidney by reducing oxidative and inflammatory stress to suppress apoptosis. Hum. Exp. Toxicol. 2021, 40, 1656-1672. [CrossRef]

41. Okda, T.; Abd-Alhaseeb, M.; Barka, K.; Ragab, N. Ginger potentiates the effects of silymarin on liver fibrosis induced by $\mathrm{CCl}_{4}$ : The role of galectin-8. Eur. Rev. Med. Pharmacol. Sci. 2019, 23, 885-891. [PubMed]

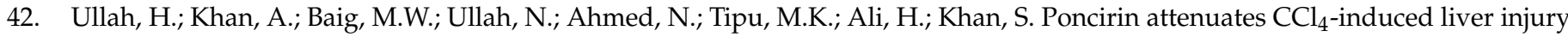
through inhibition of oxidative stress and inflammatory cytokines in mice. BMC Complement. Med. Ther. 2020, 20, 1-14. [CrossRef] [PubMed]

43. Li, H.; Yoon, J.-H.; Won, H.-J.; Ji, H.-S.; Yuk, H.J.; Park, K.H.; Park, H.-Y.; Jeong, T.-S. Isotrifoliol inhibits pro-inflammatory mediators by suppression of TLR/NF-KB and TLR/MAPK signaling in LPS-induced RAW264. 7 cells. Int. Immunopharmacol. 2017, 45, 110-119. [CrossRef] [PubMed] 
44. Xiao, Q.; Zhao, Y.; Ma, L.; Piao, R. Orientin reverses acetaminophen-induced acute liver failure by inhibiting oxidative stress and mitochondrial dysfunction. J. Pharmacol. Sci. 2022, in press. [CrossRef]

45. Bello, O.M.; Ogbesejana, A.B.; Adetunji, C.O.; Oguntoye, S.O. Flavonoids isolated from Vitex grandifolia, an underutilized vegetable, exert monoamine A \& B inhibitory and anti-inflammatory effects and their structure-activity relationship. Turk. J. Pharm. Sci. 2019, 16, 437.

46. Mohamed, T.K.; Kamal, A.M.; Nassar, M.I.; Ahmed, M.A.; Haggag, M.G.; Ezzat, H.A. Phenolic contents of Gleditsia triacanthos leaves and evaluation of its analgesic, anti-inflammatory, hepatoprotective and antimicrobial activities. Life Sci. 2013, 10, 3445-3446.

47. Jayaraman, J.; Jesudoss, V.A.S.; Menon, V.P.; Namasivayam, N. Anti-inflammatory role of naringenin in rats with ethanol induced liver injury. Toxicol. Mech. Methods 2012, 22, 568-576. [CrossRef]

48. Qian, Y.; Han, J.; Zhou, L.; Yu, Q.; Xv, J.; Jin, Z.; Yang, Y.; Jiang, L.; Lou, D. Inhibition of epidermal growth factor receptor (EGFR) reduces lipopolysaccharide (LPS)-induced activation and inflammatory cytokines in hepatic stellate cells in vitro. Med. Sci. Monit. 2018, 24, 5533. [CrossRef]

49. Yin, L.; Qi, Y.; Xu, Y.; Xu, L.; Han, X.; Tao, X.; Song, S.; Peng, J. Dioscin inhibits HSC-T6 cell migration via adjusting SDC-4 expression: Insights from iTRAQ-based quantitative proteomics. Front. Pharmacol. 2017, 8, 665. [CrossRef]

50. Liu, M.; Xu, Y.; Han, X.; Yin, L.; Xu, L.; Qi, Y.; Zhao, Y.; Liu, K.; Peng, J. Dioscin alleviates alcoholic liver fibrosis by attenuating hepatic stellate cell activation via the TLR4/MyD88/NF-kB signaling pathway. Sci. Rep. 2015, 5, 1-13.

51. Dey, P.; Panga, V.; Raghunathan, S. A cytokine signalling network for the regulation of inducible nitric oxide synthase expression in rheumatoid arthritis. PLoS ONE 2016, 11, e0161306. [CrossRef]

52. Acharya, P.; Chouhan, K.; Weiskirchen, S.; Weiskirchen, R. Cellular mechanisms of liver fibrosis. Front. Pharmacol. 2021, $12,1072$. [CrossRef] [PubMed]

53. Higashi, T.; Friedman, S.L.; Hoshida, Y. Hepatic stellate cells as key target in liver fibrosis. Adv. Drug Deliv. Rev. 2017, 121, 27-42. [CrossRef] [PubMed]

54. Bian, E.-B.; Huang, C.; Ma, T.-T.; Tao, H.; Zhang, H.; Cheng, C.; Lv, X.-W.; Li, J. DNMT1-mediated PTEN hypermethylation confers hepatic stellate cell activation and liver fibrogenesis in rats. Toxicol. Appl. Pharmacol. 2012, 264, 13-22. [CrossRef] [PubMed]

55. Di Gregorio, J.; Robuffo, I.; Spalletta, S.; Giambuzzi, G.; De Iuliis, V.; Toniato, E.; Martinotti, S.; Conti, P.; Flati, V. The epithelial-tomesenchymal transition as a possible therapeutic target in fibrotic disorders. Front. Cell Dev. Biol. 2020, 8, 1-32. [CrossRef] 